\title{
Szigetvári, Tamás (ed.) Developing Trade and Trade Policy Relations with the European Union: Experience of Visegrad Countries and Implications/ Lessons for Eastern Partners. East European Studies, no. 5. Budapest: Institute of World Economics MTA KRTK, 2014, 215pp.
}

This volume of East European Studies was based on a research executed by the Institute of World Economics of the Centre for Economic and Regional Studies at the Hungarian Academy of Sciences with a contribution from Ukrainian, Azerbaijan, Polish, Georgian and Moldavian institutes and think-tanks. The publication analyzes from several perspectives the European Neighborhood Policy, especially the Eastern Partnership. The research was financed by the International Visegrad Fund, because the Visegrad countries may provide lessons to these countries based on their experience in developing trade relations with the EU.

Owing to their history and geopolitical situation, it is really difficult for Eastern European countries to comply with the requirements imposed by the EU. Recent events in Ukraine, or Armenia's backing away from the Association Agreement with the European Union, have made it really important to deal with these issues, and help the Eastern European countries move closer to the European Union.

The volume comprises nine studies, featuring several opinions and analyses that tackle the topic from different points of view. The most positive aspect of the volume is that researchers from Central European countries evaluate their association agreements, and share their experiences to help the neighboring countries follow them on their road towards the European Union. On the other hand, researchers and experts of the Eastern Partnership countries are summing up the already achieved results of their countries, and the positive and negative experiences gained in negotiating with the European Union.

In the first study, the editor Tamás Szigetvári provides a general approach to the development of the European Union's trade policy towards neighbors. He analyzes the different forms of trade relations and assessed current trends and some future prospects. The essay offers a detailed overview of the European Economic Area, the Customs Union with Turkey, the Euro-Med agreements and the newly elaborated deep and comprehensive free trade agreements.

The following three studies summarize the experiences of the Visegrad countries. As a result of the official application for an Association Agreement, 
Poland, Hungary and Czechoslovakia signed the so-called Europe Agreements with the European Communities on 16 December 1991. General information on the Europe Agreements can be found in the joint study of Elżbieta KaweckaWyrzykowska and Sándor Meisel. In their article, the authors draw up the framework and steps of establishing the agreements. The volume continues with two country studies by the same authors. These essays give a detailed analysis of the general presumptions and motivation of two Visegrad countries, Poland and Hungary, discussing the diplomatic side of the negotiations, the tactics and negotiation strategies, analyzing specific country characteristics (sectorial and horizontal challenges), and also the compromises and outcome of the negotiations. The authors analyze the legal harmonization of traderelated topics, the main fields being sequencing, internal problems, slippages and backslidings. The institutional challenges have been approached from three aspects: negotiation, implementation and harmonization. These studies could thus serve as relevant conclusion for participant countries of the Eastern Partnership Program.

The next chapter concerns the Eastern Partners' side, with country studies on the Ukraine, Moldova, Georgia and Azerbaijan. The researchers briefly analyze their own countries along a similar structure, while each study deals with the topic independently.

In their preface, the studies provide a description of the actual state of the countryspecific EaP process by showing the general features, statistics and trends of bilateral economic relations. The Deep and Comprehensive Free Trade Area (DCFTA) process has been analyzed by the authors with a special regard to the main problems and expectations concerning the DCFTA from the EaP's point of view. They point out the major impacts in a sector-specific approach by focusing on the interests of a given EaP country, and on major barriers to realizing these. In the closing part, the authors offer suggestions, or best practices, related to the DCFTA between the EU and the EaP countries as well as recommendations on how the EU could do a better job within the Eastern Partnership initiative in general and at the DCFTA talks in particular. Beside the best practices, the EU has to take into consideration the specific character of each country. The essay is followed by country-specific analyses, which could help to understand the different situations of the EaP countries and how they differ from each other.

For example, the study on Ukraine, edited by Lidia Shynkaruk, Irina Baranovska and Olena Herasimova, emphasizes the technical field of the relations and the possible advantages and disadvantages for the core sectors of Ukrainian economy. 
Adrian Lupusor's study about Moldova concentrates on the broader framework of EU-Moldova relations, but features the sectorial issues and the special challenges of Transnistria. In the essay on the Georgia situation, Merab Kakulia sums up difficulties that the country faces regarding the DCFTA. Vugar Bayramov, the author of the article on Azerbaijan, has taken another approach, since his country is not a WTO member state, so the negotiations on DCFTA have not yet started. Finally, Zsuzsa Ludvig's study deals with one of the most important factors in the Eastern Partnership - the influence of Russia on the Eastern Partnership. The events of 2013 and today in Ukraine have clearly proved that Russia's interests in the region basically influence the cooperation between the EaP countries and the European Union.

To conclude, this volume of the East European Studies could play a significant role in understanding the bilateral relations between the EU and the EaP states. The Visegrad countries could serve as examples for the Eastern European countries, which, in turn, have to establish closer ties to realize the benefits offered by the EU. The country-specific studies help emphasize the main cooperation points as well as the gap between the EU and the countries concerned, and try to help improving the interaction between the two regions. The volume gives valuable information about the Eastern Partnership countries and, at the same time, the Neighborhood policy of the European Union.

Zsuzsanna Hegedüs is a Ph.D. student at the National University of Public Service, Budapest. She received her BA in International Economy from the Budapest Business School and her MA in International Relations. Hegedüs is currently junior research fellow at the Institute of World Economics, Research Centre for Economics and Regional Studies of the Hungarian Academy of Sciences. Her research focuses on the United States of America. 